\title{
Preparation and Characterization of Water-Soluble Polysilanes Bearing Chiral Pendant Ammonium Moieties
}

\author{
Daiyo Terunuma, ${ }^{\dagger}$ Koji Nagumo, Norihiko Kamata, Koji Matsuoka, \\ and Hiroyoshi KuzuHara \\ Department of Functional Materials Science, Faculty of Engineering, Saitama University, \\ Shimo-okubo 255, Urawa, Saitama 338-8570, Japan
}

(Received June 17, 1999)

\begin{abstract}
The preparation and characterization of new amphiphilic polysilanes containing chiral pendant ammonium groups are described. Polyalkylphenylsilanes $\left(\right.$ alkyl $\left.; \mathrm{C}_{1}-\mathrm{C}_{8}\right)(\mathbf{I})$ were prepared, and the Friedel-Crafts reaction of I was carried out to give $p$-chloromethylated polysilanes (II). II were treated with optically active amines such as $N, N$-dimethyl- $\alpha$-methylbenzylamine (1), $N, N$-dimethylphenylalaninol (2), $N, N$-dimethyl-O-acethylphenylalaninol (3), $N, N$-dimethyl-iso-leucinol (4), N,N-dimethylleucinol (5) and $N, N$-dimethyl-1-phenylethanol (6) to give the corresponding amphiphilic polysilanes bearing chiral pendant ammonium moieties. All polymers prepared were soluble in water, ethanol and acetonitrile. The circular dichromic spectra (CD) of the polymers in ethanol showed that the polymer had a screw-sense main chain
\end{abstract}

KEY WORDS Water-Soluble Polysilane / Opticaliy Active Pendant/Chloromethylation of Polysilane/

Polysilanes display unique characteristics such as UV absorption and luminescence due to $\sigma$-conjugation of the $\mathrm{Si}-\mathrm{Si}$ main chain. It is important to control the conformation of the $\mathrm{Si}-\mathrm{Si}$ main chain to develop applications of the polysilanes to functional materials. Attention has been focused on the preparation and characterization of amphiphilic polysilanes carrying ether, ${ }^{1}$ phenol, ${ }^{2}$ and ammonium moieties ${ }^{3}$ in the side chain, since they are expected to have potential for highly orientated structures of the polysilane main chain. Langmuir Blodgett film prepared from a polysilane which has phenollic groups in the side chain shows clear anisotropy in its UV spectra. ${ }^{2}$

There are few reports on the preparation of polysilanes bearing asymmetric moieties. ${ }^{4,5}$ Fujiki reported that polysilanes bearing an optically active 2methylbutyl group exhibited strong UV absorption and luminescence due to the screw-sense conformation of the main chain. ${ }^{4 a}$ Most functionalized polysilanes, except ammonium functionalized ones, ${ }^{3}$ were prepared by the Wurtz reaction using dichlorosilane derivatives bearing optically active groups on silicon. ${ }^{4}$ In this method, asymmetric substituents are strictly limited, because they must be stable under the Wurtz coupling conditions.

Introduction of functional groups to a preformed polysilane is another possibility for preparation of functionalized polysilanes. The chloromethylation reaction of phenyl substituted polysilane is expected to be a novel method for the preparation of organofunctional polysilanes, ${ }^{3,6}$ since numerous preparative methods of functional materials through chloromethylated polystyrene have been widely developed. We reported the preparation and characterization of poly- $n$-hexylphenylsilane with an optically active amine, $N, N$-dimethyl- $\alpha$-methylbenzylamine (1). ${ }^{7}$ In this paper, further syntheses of chloromethylated polysilanes and characterization of new polysilanes bearing optically active ammonium derivatives are described.

\footnotetext{
${ }^{\dagger}$ To whom correspondence should be addressed.
}

\section{RESULTS AND DISCUSSION}

Preparation of Poly-n-alkylphenylsilane $(\boldsymbol{I})$

I $\left[\mathrm{R}=\mathrm{CH}_{3}\right.$ (a), $\mathrm{C}_{2} \mathrm{H}_{5}$ (b), $\mathrm{C}_{3} \mathrm{H}_{7}$ (c), $\mathrm{C}_{4} \mathrm{H}_{9}$ (d), $\mathrm{C}_{5} \mathrm{H}_{11}(\mathrm{e}), \mathrm{C}_{6}$ $\mathrm{H}_{13}$ (f), $\mathrm{C}_{7} \mathrm{H}_{15}$ (g), $\mathrm{C}_{8} \mathrm{H}_{17}(\mathrm{~h})$ ] were prepared by the Wurtz reaction under irradiation of supersonic waves to make the polysilanes monomodal (Scheme 1). ${ }^{8}$ The results are shown in Table I. Ic and Id were obtained as waxy solids, both of which were insoluble in common organic solvents such as toluene, tetrahydrofuran (THF), and benzene. Only Ib was yielded in a bimodal molecular weight distribution, and the others were monomodal as expected. The UV spectra of the poly- $n$-alkylphenylsilanes were measured in chloroform, and the spectra of If, Ig, and Ih exhibited similar absorption maximum $\left(\lambda_{\max }\right)$ and molar absorptivity $\left(\varepsilon_{\max }\right)$.

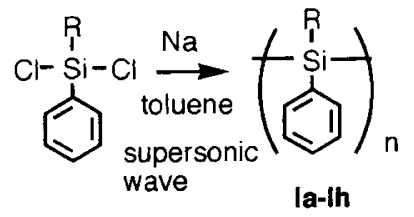

$$
\begin{aligned}
& \mathrm{R}=\mathrm{CH}_{3}(\mathrm{a}), \mathrm{C}_{2} \mathrm{H}_{5} \text { (b), } \mathrm{C}_{3} \mathrm{H}_{7} \text { (c), } \mathrm{C}_{4} \mathrm{H}_{9} \text { (d), } \mathrm{C}_{5} \mathrm{H}_{11}(\mathrm{e}), \\
& \mathrm{C}_{6} \mathrm{H}_{13} \text { (f), } \mathrm{C}_{7} \mathrm{H}_{15} \text { (g), } \mathrm{C}_{8} \mathrm{H}_{17} \text { (h) }
\end{aligned}
$$

Scheme 1. Preparation of polysilanes.

\begin{tabular}{|c|c|c|c|c|}
\hline Compound & $\frac{\text { Yield }}{\%}$ & $M_{w}\left(\times 10^{4}\right)^{\mathrm{a}}$ & $\frac{\lambda_{\max }{ }^{b}}{n m}$ & $\varepsilon_{\max }$ \\
\hline Ia & 56 & 0.9 & 332 & 4100 \\
\hline Ib & 10 & $28(36 \%), 8.0(64 \%)^{\mathrm{c}}$ & 341 & 8500 \\
\hline Ic & 17 & Insoluble & - & - \\
\hline Id & 18 & Insoluble & 一 & - \\
\hline Ie & 36 & 14.6 & 347 & 12400 \\
\hline If & 23 & 15.0 & 347 & 16100 \\
\hline Ig & 23 & 13.6 & 347 & 16300 \\
\hline Ih & 11 & 13.2 & 347 & 17200 \\
\hline
\end{tabular}

Table I. Preparation of poly- $n$-alkylphenylsilanes

${ }^{\mathrm{a} P o l y s t y r e n e ~ s t a n d a r d ~ i n ~ t e t r a h y d r o f u r a n . ~}{ }^{\mathrm{b}} \mathrm{In} \mathrm{CHCl}_{3}$.

${ }^{\mathrm{c}}$ Bimodal GPC traces appeared. 


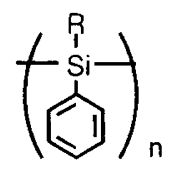

la-lh

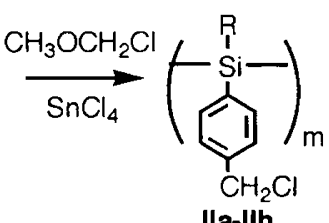

Ila-Ilh
$\mathrm{R}=\mathrm{CH}_{3}$ (a), $\mathrm{C}_{2} \mathrm{H}_{5}$ (b), $\mathrm{C}_{3} \mathrm{H}_{7}$ (c), $\mathrm{C}_{4} \mathrm{H}_{9}$ (d), $\mathrm{C}_{5} \mathrm{H}_{11}$ (e), $\mathrm{C}_{6} \mathrm{H}_{13}(\mathrm{f}), \mathrm{C}_{7} \mathrm{H}_{15}(\mathrm{~g}), \mathrm{C}_{8} \mathrm{H}_{17}$ (h)

Scheme 2. Chloromethylation reaction of Ia-Ih.

Table II. Chloromethylation of I

\begin{tabular}{|c|c|c|c|c|c|}
\hline Compound & $\frac{\text { Yield }}{\%}$ & $\begin{array}{c}\begin{array}{c}\text { Substitutuion } \\
\text { ratio }^{\mathrm{a}}\end{array} \\
\%\end{array}$ & $M_{w}\left(\times 10^{4}\right)^{\mathrm{b}}$ & $\frac{\lambda_{\max }{ }^{\mathrm{c}}}{\mathrm{nm}}$ & $\varepsilon_{\max }$ \\
\hline IIa & - & - & - & - & - \\
\hline IIb & 87 & 80 & 0.7 & 339 & 6100 \\
\hline IIc & 65 & 88 & $\begin{array}{l}43(20 \%){ }^{d} \\
2.2(80 \%)\end{array}$ & 347 & 14300 \\
\hline IId & 42 & 68 & 2.6 & 347 & 18200 \\
\hline IIe & 49 & -100 & 2.0 & 345 & 11100 \\
\hline IIf & 90 & -100 & 1.0 & 346 & 10500 \\
\hline IIg & 63 & -100 & 2.7 & 347 & 12200 \\
\hline IIh & 55 & $\sim 100$ & 1.8 & 346 & 7800 \\
\hline
\end{tabular}

${ }^{\mathrm{a}}$ Estimated from ${ }^{1} \mathrm{H}$ NMR spectrum. ${ }^{\mathrm{b}}$ Polystyrene standard in tetrahydrofuran. ${ }^{\mathrm{c}}$ In $\mathrm{CHCl}_{3}$. ${ }^{\mathrm{d}}$ Bimodal GPC traces appeared.

\section{Chloromethylation Reaction of $\boldsymbol{I}$}

Friedel-Crafts chloromethylation using a tin tetrachloride catalyst ${ }^{6 a}$ was performed to give the corresponding chloromethylated polysilanes (II) (Scheme 2). The results are summarized in Table II. Substitution of the chloromethyl group was estimated by the intensity ratio of aromatic protons and methylene protons of the chloromethyl substituent in the ${ }^{1} \mathrm{H}$ NMR of the resulting polysilane derivatives. Although successful preparation of chloromethylated polymethylphenylsilane is described in the literature ${ }^{6 \mathrm{~b}}$ extensive degradation of the polysilane main chain and partial ipso-attack to silicon observed in our case (IIa) may be due to the relatively higher reaction temperature optimized for complete chloromethylation of IIf. Other polysilanes prepared were chloromethylated successfully, although partial cleavage of the polysilane main chain was observed after chloromethylation of $\mathbf{I b}, \mathbf{I e}, \mathbf{I f}, \mathbf{I g}$, and $\mathbf{I h}$, and the average molecular weight of the corresponding IIb, IIe, IIf, IIg, and IIh decreased to about one-seventh that of the starting polysilanes. However, it is considered that IIIb, IIe, IIf, IIg, and IIh were appropriate materials to investigate the behavior of the polysilane main chain, because they have over 40 units of the $\mathrm{Si}-\mathrm{Si}$ bond and there is no detectable increase in the IR spectra around $1100 \mathrm{~cm}^{-1}$ absorption due to $\mathrm{Si}-\mathrm{O}-\mathrm{Si}$. The insoluble polymers, Ic and Id, were treated with chloromethyl methyl ether in the presence of tin tetrachloride under similar reaction conditions. The reaction mixture became homogeneous at the end of the reaction, although it was heterogeneous at the beginning of the reaction. The usual work-up of the reaction mixture gave soluble IIc and IId, respectively. These results suggest that the insolubility of Ic and Id is based not on cross-links but on relatively higher molecular weights of the polysilanes. It is difficult to determine the position of the chlo-

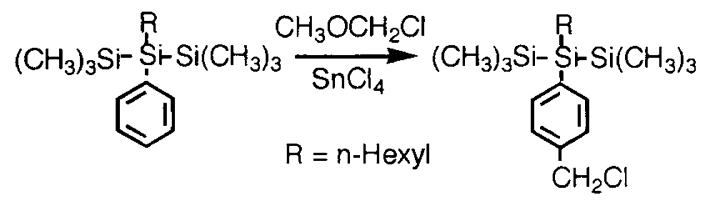

Scheme 3. Chloromethylation reaction of 2-hexyl-1, 1, 1, 3, 3, 3-hexamethyl-2-phenyltrisilane.

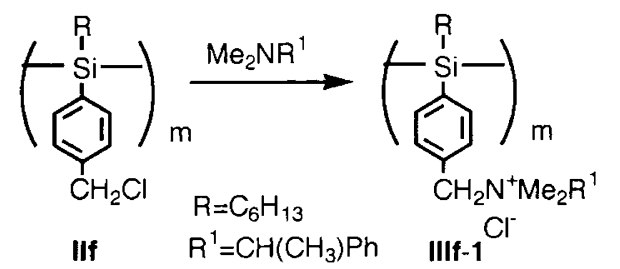

Scheme 4. Reaction of IIf with optically active amine.

romethyl substituent of the polymer I directly, since all NMR spectra of the chloromethylated polysilanes showed broad peaks as usual. Nevertheless, the chloromethylation of the polysilanes, which have a more bulky silane substituent than the model compound, 2hexyl-1,1,1,3,3,3-hexamethyl-2-phenyltrisilane, may occur at the $p$-position ${ }^{7}$ (Scheme 3 ).

\section{Preparation and Characterization of Ammonium Deriva-}

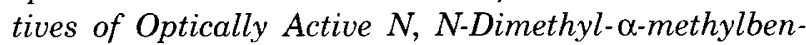
zylamine

At first, IIf was treated with (+)-, (-)-, and ( \pm$)_{-N} \mathrm{~N} N$ dimethyl- $\alpha$-methylbenzylamine (1) to give polysilanes bearing optically active pendant ammonium moieties (IIIf- $(+)-\mathbf{1}$, IIIf- $(-)-\mathbf{1}$, and IIIf- $( \pm)-\mathbf{1})$, respectively (Scheme 4). All polysilane derivatives obtained were soluble in water, ethanol, and acetonitrile. The UV spectrum of IIIf- $(+)-\mathbf{1}$ showed an absorption due to the $\mathrm{Si}-\mathrm{Si}$ $\sigma$-bonds in the 320 to $355 \mathrm{~nm}$ region ( $\lambda_{\max } 339 \mathrm{~nm}, \varepsilon 6800$ in EtOH). The CD spectrum of IIIf- $(+)-\mathbf{1}$ showed a negative broad absorption $\left(\lambda_{\max } 334 \mathrm{~nm}, \varepsilon^{-0.72}\right.$ (Si unit) in EtOH) in a similar region to the UV absorption and positive broad absorption around $300 \mathrm{~nm}(\varepsilon+0.65$ (Si unit)) probably due to aromatic groups (Figure 1). The CD spectrum of IIIf-( -$)-\mathbf{1}$ exhibited a symmetrical pattern $\left(\lambda_{\max } 336 \mathrm{~nm}, \varepsilon+0.30\right.$ (Si unit), and $\lambda_{\max } 295 \mathrm{~nm}, \varepsilon-$ 0.65 (Si unit) in EtOH) to that of IIIf- $(+)-1$ (Figure 2). No CD absorption was observed in the spectrum of IIIf$( \pm)-1$. These results indicate that the polysilane main chain of IIIf- $(+)-\mathbf{1}$ and IIIf- $(-)-\mathbf{1}$ has an opposite, oneway screw-like conformation. IIIf- $(+)-1$ obtained from the reaction of a $50 \%$ chloromethylated IIf and (+)-1 gave nearly the same CD spectrum as that of the completely substituted IIIf- $(+)-\mathbf{1}$. It is apparent that a 50\% of the substituent effectively controls the conformation of the polysilane main chain.

Each chloromethylated polysilane (II) described in Table II was treated with $(+)-\mathbf{1}$ to give the corresponding ammonium derivatives (III- $(+)-\mathbf{1})$. The patterns of the UV and CD spectra of IIIb, IIIc, IIId, IIIe, IIIg, and IIIh- $(+)-\mathbf{1}$ were similar to that of IIIf- $(+)-\mathbf{1}$. The value of $\varepsilon_{\max }$ of IIIf- $(+)-\mathbf{1}$ was largest among the polysilanes prepared here. 


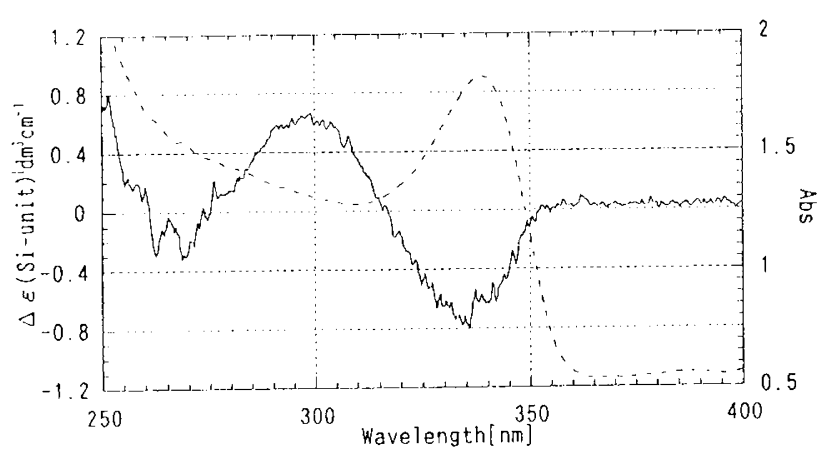

Figure 1. CD (- ) and UV (- _-) spectra of IIIf- $(+)-1$ in $99 \%$ $\mathrm{EtOH}$.

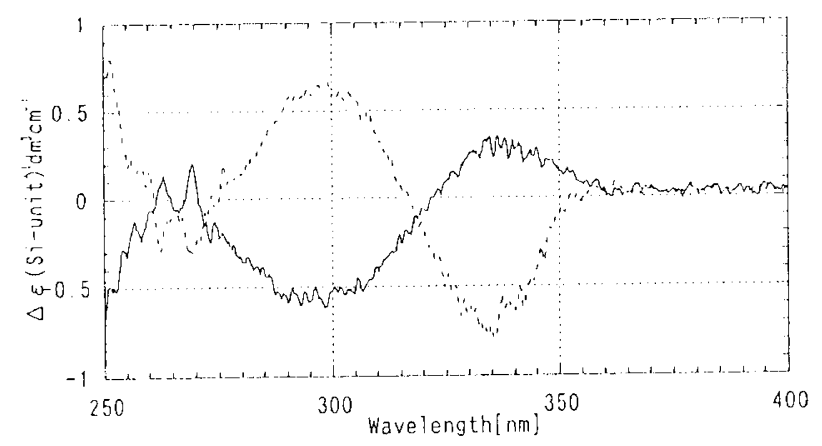

Figure 2. CD spectra of IIIf-(+)-1(- - -) and IIIf- $(-)-\mathbf{1}(-)$ in $99 \%$ $\mathrm{EtOH}$.

\section{Effects of the Structure of Optically Active Amine}

IIf was treated with other optically active amines such as (-)- $N, N$-dimethylphenylalaninol $(\mathbf{2}),(+)-N, N$-dimethyl-O-acethylphenylalaninol (3), (+)- $N, N$-dimethyliso-leucinol (4), (+)- $N, N$-dimethylleucinol (5), or (-)- $N$, $N$-dimethyl-1-phenylethanol (6) (Figure 3) to afford the corresponding amphiphilic polysilanes (IIIf-(-)-2, IIIf$(+)-\mathbf{3}$, IIIf- $(+)-\mathbf{4}$, IIIf- $(+)-\mathbf{5}$, and IIIf- $(-)-6)$. Amines 1 and 6 have a phenyl group attached to the asymmetric center directly, and $\mathbf{2}$ and $\mathbf{3}$ bear a phenyl group on the carbon adjacent to the asymmetric center. Amines $\mathbf{4}$ and 5 have no phenyl group. All ammonium derivatives obtained were soluble in water, ethanol, and acetonitrile. The CD spectra of the polysilanes bearing these amines in ethanol are shown in Figure 4.

All polysilanes bearing optically active ammonium moieties showed negative Cotton effects around $330 \mathrm{~nm}$ based on the $\mathrm{Si}-\mathrm{Si} \sigma$ conjugation in their $\mathrm{CD}$ spectra (Figure 4). This means that all chiral pendant ammonium moieties control the conformation of the polysilane main chains effectively.

Broad positive Cotton effects around $300 \mathrm{~nm}$ were observed in the CD spectra of IIIf- $(+)-1$ (Figure 1) and IIIf(-)-6 (Figure 4e) in which phenyl groups were attached to the asymmetric center directly. However, absorption was not found in the spectra of IIIf- $(+)-4$ (Figure 4c) and IIIf- $(+)-5$ (Figure 4d) which did not have a phenyl group in the optically active amines. Positive absorption was also not found in those of IIIf- $(-)-2$ (Figure $4 \mathrm{a}$ ) and IIIf- $(+)-3$ (Figure $4 \mathrm{~b}$ ) even though the amines had a phenyl group. These results suggest that the broad positive Cotton effects around $280-300 \mathrm{~nm}$ come from the

$$
\begin{gathered}
\mathrm{PhCH}_{2} \mathrm{C}^{*} \mathrm{HCH}_{2} \mathrm{OH} \\
\mathrm{N}\left(\mathrm{CH}_{3}\right)_{2}
\end{gathered}
$$

2<smiles>CCC(CC)N(C)C</smiles><smiles>CN(C)CC(O)c1ccccc1</smiles>

6
$\mathrm{PhCH}_{2} \mathrm{C}_{1}^{*} \mathrm{HCH}_{2} \mathrm{OOCCH}_{3}$
$\mathrm{~N}\left(\mathrm{CH}_{3}\right)_{2}$

3<smiles>CCCC(C)N(C)CO</smiles>

5
Figure 3. Optically active amines.

phenyl groups attached to the asymmetric carbon center directly.

\section{EXPERIMENTAL}

The NMR spectra were determined at $400 \mathrm{MHz}$ with a Bruker AM400 and ARX400 spectrometer in $\mathrm{CDCl}_{3}$ using tetramethylsilane (TMS) as an internal standard or in dimethyl sulfoxide (DMSO)- $d_{6}$. UV, CD, and IR spectra were measured with a JASCO V 550 , a J-720 W, and an FT-IR-300E, respectively. Optical rotations were measured with a JASCO DIP-360 polarimeter. Molecular weights were determined by a TOSOH SD-8000 with polystyrene standard. The irradiation of supersonic waves was carried out by a Honda W-221 ultrasound bath. All reactions were performed under an argon atmosphere. Alkylphenyldichlorosilanes were prepared by treating trichlorophenylsilane with appropriate Grignard reagents.

\section{Preparation of Polysilanes}

A representative procedure is described. A solution of dichlorohexylphenylsilane $(12.0 \mathrm{~g}, 45.9 \mathrm{mmol})$ in dry toluene $(12 \mathrm{~mL})$ was added by syringe to a mixture of sodium dispersion prepared from sodium $(2.11 \mathrm{~g}, 91.9$ mmol) in dry toluene $(60 \mathrm{~mL})$ under high speed stirring and irradiation of supersonic waves. The mixture was stirred for $1 \mathrm{~h}$ and then dry 2-propanol (15 mL) was added to the mixture. The reaction mixture was added to 2-propanol ( $250 \mathrm{~mL}$ ) with stirring. Precipitated mixture was collected by filtration. Toluene $(200 \mathrm{~mL})$ was added to the mixture and washed with water $(100 \mathrm{~mL})$ three times. The organic layer was dried $\left(\mathrm{Na}_{2} \mathrm{SO}_{4}\right)$. The solvent was evaporated. Toluene $(5 \mathrm{~mL})$ was added to the residue, and the solution was added to 2-propanol (100 $\mathrm{mL}$ ). The precipitate was separated by filtration to give a white powder in $2.04 \mathrm{~g}(23 \%)$ yield. ${ }^{1} \mathrm{H} \mathrm{NMR}\left(\mathrm{CDCl}_{3}\right) \delta$ - 0.5-1.4 (broad, $13 \mathrm{H}, \mathrm{C}_{6} \mathrm{H}_{13}$ ), 5.9-7.2 (broad, 5H, Ar).

\section{Preparation of Chloromethylated Polysilanes}

A representative procedure is described. Tin tetrachloride $(1.0 \mathrm{~g}, 3.84 \mathrm{mmol})$ was added to a solution of If $(1.0 \mathrm{~g}$, $5.25 \mathrm{mmol} / \mathrm{phenyl}$ group) and large excess of chloromethyl methyl ether $(10 \mathrm{~mL})$ in chloroform $(15 \mathrm{~mL})$ by syringe at $0^{\circ} \mathrm{C}$. The mixture was stirred at $0^{\circ} \mathrm{C}$ for $6 \mathrm{~h}$ and $12 \mathrm{~h}$ at room temperature. The reaction mixture was washed with water several times. The water was ex- 

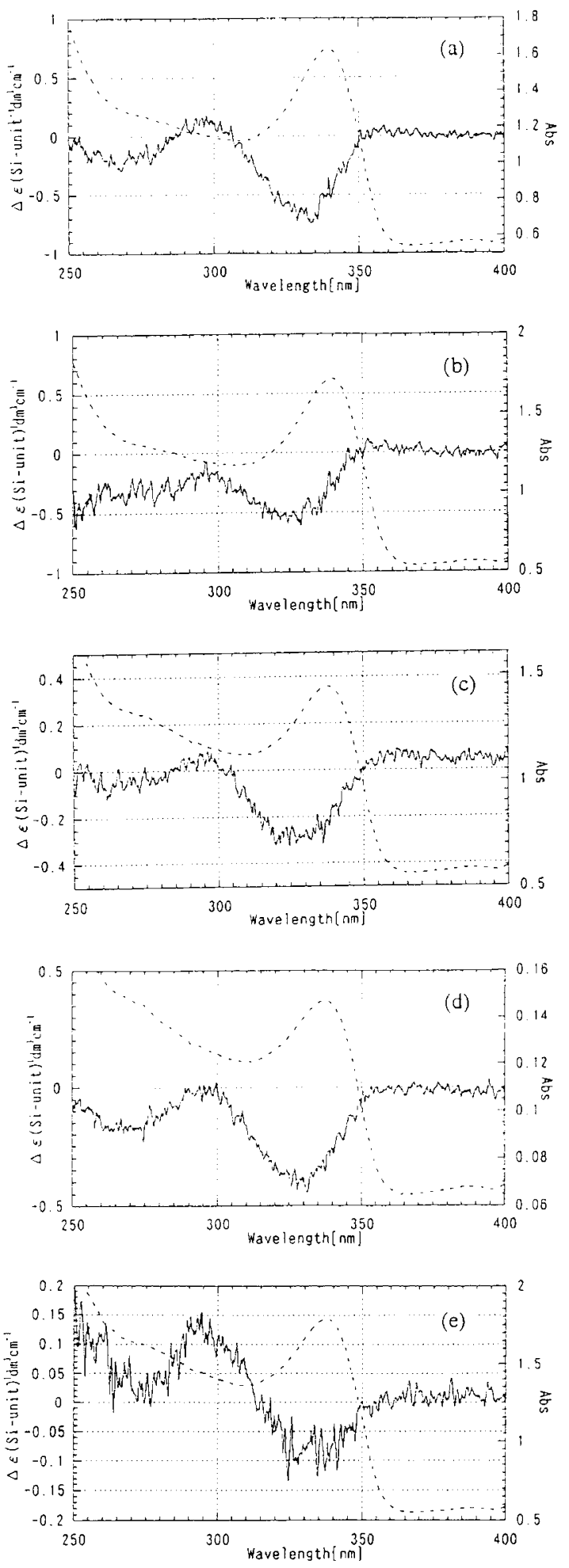

Figure 4. CD (-) and UV (- - -) spectra of IIIf- $(-)-2($ a), IIIf- $(+)$ 3 (b), IIIf- $(+)-4$ (c), IIIf- $(+)-5$ (d), and IIIf- - - -6 (e) in 99\% EtOH.

tracted with chloroform $(5 \mathrm{~mL})$ three times. The combined chloroform solution was dried $\left(\mathrm{Na}_{2} \mathrm{SO}_{4}\right)$. The solvent was removed and THF $(2 \mathrm{~mL})$ was added to the residue. The THF solution was added to methanol (200 $\mathrm{mL}$ ). The precipitate was separated by filtration to give IIf (white powder) in $1.13 \mathrm{~g}(90 \%)$ yield. ${ }^{1} \mathrm{H}$ NMR $\left(\mathrm{CDCl}_{3}\right) \delta-0.5-1.4\left(\right.$ broad, $\left.13 \mathrm{H}, \mathrm{C}_{6} \mathrm{H}_{13}\right), 4.46($ broad s, 2 $\mathrm{H}, \mathrm{CH}_{2} \mathrm{Cl}$ ), 5.9-7.2 (broad, $5 \mathrm{H}, \mathrm{Ar}$ ).

\section{Preparation of Optically Active Amines}

Optically active $N, N$-dimethylamines were prepared as described in the literature. ${ }^{9}$ A representative procedure is described. (+)- $\alpha$-Methylbenzylamine (14.5 g, $0.12 \mathrm{~mol})\left([\alpha]_{\mathrm{D}}+37.3^{\circ}(\mathrm{c} 1\right.$, EtOH $) ;$ lit. $^{9}[\alpha]_{\mathrm{D}}+40.3^{\circ}$ (neat)) was slowly added to formic acid (98\% solution) (28.5 mL, $0.6 \mathrm{~mol}$ ). Formaldehyde ( $37 \%$ aqueous solution) $(31.5 \mathrm{~mL}, 0.36 \mathrm{~mol})$ was added to the mixture. The reaction mixture was warmed to start decarboxylation reaction. The mixture was then made to stand at room temperature till spontaneous degradation was finished. The mixture was stirred at $100^{\circ} \mathrm{C}$ for $8 \mathrm{~h}$. Four molar hydrochloric acid $(60 \mathrm{~mL})$ was added to the mixture, and the solvent was evaporated. To the residue $18 \mathrm{M} \mathrm{NaOH}$ $(42 \mathrm{~mL})$ was added. The reaction mixture was extracted with benzene $(30 \mathrm{~mL})$ three times. The combined organic layer and extracts was dried $\left(\mathrm{K}_{2} \mathrm{CO}_{3}\right)$. Evaporation and distillation gave 1 in $13.9 \mathrm{~g}(77 \%)$ yield. $\mathrm{Bp} 85^{\circ} \mathrm{C} / 22$ Torr. ${ }^{1} \mathrm{H} \mathrm{NMR}\left(\mathrm{CDCl}_{3}\right) \delta 1.37\left(\mathrm{~d}, J=7.1 \mathrm{~Hz}, 3 \mathrm{H}, \mathrm{CCH}_{3}\right), 2.19(\mathrm{~s}$, $\left.6 \mathrm{H}, \mathrm{NCH}_{3}\right), 3.24$ (q, $\left.J=7.1 \mathrm{~Hz}, 1 \mathrm{H}, \mathrm{PhCH}\right), 7.2-7.4$ (m, 5 $\mathrm{H}, \mathrm{Ar}) .[\alpha]_{\mathrm{D}}+47.6$ (c10, EtOH).

2 ; Yield $94 \%$. Bp $140^{\circ} \mathrm{C} / 3$ Torr. $[\alpha]_{\mathrm{D}}-2.1^{\circ}$ (c1, EtOH). ${ }^{1} \mathrm{H} \mathrm{NMR}\left(\mathrm{CDCl}_{3}\right) \delta 2.25-2.28(\mathrm{~m}, 1 \mathrm{H}, \mathrm{CH}), 2.35(\mathrm{~s}, 6 \mathrm{H}$, $\left.\mathrm{NCH}_{3}\right), 2.75-3.0\left(\mathrm{~m}, 2 \mathrm{H}, \mathrm{PhCH}_{2}\right), 3.22($ broad s, $1 \mathrm{H}$, $\mathrm{OH}), 3.24-3.45\left(\mathrm{~m}, 2 \mathrm{H}, \mathrm{OCH}_{2}\right), 7.0-7.4$ (m, 5H, Ar). 3 ; Yield $83 \%$. Bp $170^{\circ} \mathrm{C} / 22$ Torr. $[\alpha]_{\mathrm{D}}+28.9^{\circ}$ (c1, EtOH). ${ }^{1} \mathrm{H} \mathrm{NMR}\left(\mathrm{CDCl}_{3}\right) \delta 2.01\left(\mathrm{~s}, 3 \mathrm{H}, \mathrm{C}(=\mathrm{O}) \mathrm{CH}_{3}\right), 2.39(\mathrm{~s}, 6 \mathrm{H}$, $\left.\mathrm{NCH}_{3}\right), 2.44-2.66(\mathrm{~m}, 1 \mathrm{H}, \mathrm{CH}), 2.87-3.10(\mathrm{~m}, 2 \mathrm{H}$, $\left.\mathrm{PhCH}_{2}\right), 3.95-4.22\left(\mathrm{~m}, 2 \mathrm{H}, \mathrm{OCH}_{2}\right), 7.1-7.4(\mathrm{~m}, 5 \mathrm{H}, \mathrm{Ar})$. 4 ; Yield $88 \%$. Bp $110^{\circ} \mathrm{C} / 7$ Torr. $[\alpha]_{\mathrm{D}}+20.8^{\circ}$ (c1.7, EtOH). ${ }^{1} \mathrm{H}$ NMR $\left(\mathrm{CDCl}_{3}\right) \delta 0.80\left(\mathrm{~d}, J=7.0 \mathrm{~Hz}, 3 \mathrm{H}, \mathrm{C}^{*}\right.$ $\left.\mathrm{CH}_{3}\right), 0.90\left(\mathrm{t}, 3 \mathrm{H}, J=7.3 \mathrm{~Hz}, \mathrm{CCH}_{3}\right), 1.15-1.30(\mathrm{~m}, 1 \mathrm{H}$, $\mathrm{NCCH}), 1.35-1.55,1.55-1.75\left(\mathrm{~m}, 2 \mathrm{H}, \mathrm{MeCH}_{2}\right), 2.38(\mathrm{~s}$, $\left.6 \mathrm{H}, \mathrm{NCH}_{3}\right), 2.35-2.5(\mathrm{~m}, 1 \mathrm{H}, \mathrm{NCH}), 3.29(\mathrm{t}, J=10.2 \mathrm{~Hz}$, $1 \mathrm{H}, \mathrm{OCH}_{2}$ ), 3.51 (q, $J=5.5 \mathrm{~Hz}, 1 \mathrm{H}, \mathrm{OCH}_{2}$ ). 5 ; Yield $65 \%$. Bp $115^{\circ} \mathrm{C} / 37$ Torr. $[\alpha]_{\mathrm{D}}+35.2^{\circ}$ (c1.7, EtOH). ${ }^{1} \mathrm{H}$ NMR $\left(\mathrm{CDCl}_{3}\right) \delta 0.90\left(\mathrm{t}, J=7.1 \mathrm{~Hz}, 6 \mathrm{H}, \mathrm{CH}_{3}\right), 0.85-1.05,1.20$ $1.40\left(\mathrm{~m}, 2 \mathrm{H}, \mathrm{NCCH}_{2}\right), 1.40-1.60(\mathrm{~m}, 1 \mathrm{H}, \mathrm{MeCH}), 2.24(\mathrm{~s}$, $\left.6 \mathrm{H}, \mathrm{NCH}_{3}\right), 2.55-2.77\left(\mathrm{~m}, 1 \mathrm{H}, \mathrm{C}^{*} \mathrm{H}\right), 3.21(\mathrm{t}, J=10.6 \mathrm{~Hz}$, $1 \mathrm{H}, \mathrm{OCH}_{2}$ ), 3.49 (q, $J=4.8 \mathrm{~Hz}, 1 \mathrm{H}, \mathrm{OCH}_{2}$ ). 6 ; Yield $83 \%$. Bp $100^{\circ} \mathrm{C} / 2$ Torr. $[\alpha]_{\mathrm{D}}-12.3^{\circ}$ (c1, EtOH). ${ }^{1} \mathrm{H}$ NMR $\left(\mathrm{CDCl}_{3}\right) \delta 2.34\left(\mathrm{~s}, 6 \mathrm{H}, \mathrm{NCH}_{3}\right), 2.3-2.6\left(\mathrm{~m}, 2 \mathrm{H}, \mathrm{NCH}_{2}\right)$, 3.99 (broad s, $1 \mathrm{H}, \mathrm{OH}), 4.68(\mathrm{dd}, J=10.2 \mathrm{~Hz}, 3.9 \mathrm{~Hz}$, $\mathrm{PhCH}$ ), 7.2-7.5 (m, 5H, Ar).

\section{Preparation of Ammonium Derivatives}

A representative procedure is described. A mixture of IIf (100 mg, $0.42 \mathrm{mmol} /$ silicon) and (+)-1 (312 mg, 2.09 $\mathrm{mmol})$ in 2-propanol ( $1 \mathrm{~mL})$ was refluxed for $12 \mathrm{~h}$ in the dark, followed by the addition of hexane $(100 \mathrm{~mL})$. The precipitated polymer was separated by filtration to give a white solid (IIIf- $(+)-1$ ) in $144 \mathrm{mg}(88 \%)$ yield. ${ }^{1} \mathrm{H}$ NMR $\left(\mathrm{DMSO}-d_{6}\right) \delta 0-1.5\left(13 \mathrm{H}, \mathrm{C}_{6} \mathrm{H}_{13}\right), 1.7-2.2\left(3 \mathrm{H}, \mathrm{NCCH}_{3}\right)$, $2.4-3.2\left(6 \mathrm{H}, \mathrm{NCH}_{3}\right), 4.0-5.0\left(2 \mathrm{H}, \mathrm{NCH}_{2}\right), 5.0-6.0(1 \mathrm{H}$, $\mathrm{NCH}), 7.0-8.1(9 \mathrm{H}, \mathrm{Ar})$. IIIb-(+)-1 (white solid); Yield quant. ${ }^{1} \mathrm{H}$ NMR (DMSO- $\left.d_{6}\right) \delta 0.0-1.5\left(5 \mathrm{H}, \mathrm{C}_{2} \mathrm{H}_{5}\right), 1.7-$ $2.2\left(3 \mathrm{H}, \mathrm{NCCH}_{3}\right), 2.4-3.2\left(6 \mathrm{H}, \mathrm{NCH}_{3}\right), 4.0-5.0(2 \mathrm{H}$, $\left.\mathrm{NCH}_{2}\right), 5.0-6.0(1 \mathrm{H}, \mathrm{NCH}), 7.0-8.1(9 \mathrm{H}, \mathrm{Ar})$. IIIc- $(+)-$ 1 (white solid); Yield 91\%. ${ }^{1} \mathrm{H}$ NMR (DMSO- $d_{6}$ ) $\delta 0.0-$ $1.5\left(7 \mathrm{H}, \mathrm{C}_{3} \mathrm{H}_{7}\right), 1.7-2.2\left(3 \mathrm{H}, \mathrm{NCCH}_{3}\right), 2.4-3.2(6 \mathrm{H}$, $\left.\mathrm{NCH}_{3}\right), 4.0-5.0\left(2 \mathrm{H}, \mathrm{NCH}_{2}\right), 5.0-6.0(1 \mathrm{H}, \mathrm{NCH}), 7.0-$ 8.1 (9H, Ar). IIId- $(+)-1$ (white solid); Yield $96 \% .{ }^{1} \mathrm{H}$ NMR (DMSO- $\left.d_{6}\right) \delta 0.0-1.5\left(9 \mathrm{H}, \mathrm{C}_{4} \mathrm{H}_{9}\right), 1.7-2.2(3 \mathrm{H}$, 
$\left.\mathrm{NCCH}_{3}\right), 2.4-3.2\left(6 \mathrm{H}, \mathrm{NCH}_{3}\right), 4.0-5.0\left(2 \mathrm{H}, \mathrm{NCH}_{2}\right), 5.0$ $-6.0(1 \mathrm{H}, \mathrm{NCH}), 7.0-8.1$ (9H, Ar). IIIe- $(+)-1$ (pale yellow solid); Yield quant. ${ }^{1} \mathrm{H}$ NMR (DMSO- $\left.d_{6}\right) \delta 0.0-1.5$ $\left(11 \mathrm{H}, \quad \mathrm{C}_{5} \mathrm{H}_{11}\right), \quad 1.7-2.2\left(3 \mathrm{H}, \mathrm{NCCH}_{3}\right), 2.4-3.2(6 \mathrm{H}$, $\left.\mathrm{NCH}_{3}\right), 4.0-5.0\left(2 \mathrm{H}, \mathrm{NCH}_{2}\right), 5.0-6.0(1 \mathrm{H}, \mathrm{NCH}), 7.0-$ 8.1 (9H, Ar). IIIg-(+)-1 (white solid) ; Yield 88\%. ${ }^{1} \mathrm{H}$ NMR (DMSO- $\left.d_{6}\right) \delta 0.0-1.5\left(15 \mathrm{H}, \mathrm{C}_{7} \mathrm{H}_{15}\right), 1.7-2.2(3 \mathrm{H}$, $\left.\mathrm{NCCH}_{3}\right), 2.4-3.2\left(6 \mathrm{H}, \mathrm{NCH}_{3}\right), 4.0-5.0\left(2 \mathrm{H}, \mathrm{NCH}_{2}\right), 5.0$ $-6.0(1 \mathrm{H}, \mathrm{NCH}), 7.0-8.1(9 \mathrm{H}, \mathrm{Ar})$. IIIh- $(+)-1$ (white solid) ; Yield $82 \% .{ }^{1} \mathrm{H}$ NMR (DMSO- $\left.d_{6}\right) \delta 0.0-1.5(17 \mathrm{H}$, $\left.\mathrm{C}_{8} \mathrm{H}_{17}\right), 1.7-2.2\left(3 \mathrm{H}, \mathrm{NCCH}_{3}\right), 2.4-3.2\left(6 \mathrm{H}, \mathrm{NCH}_{3}\right), 4.0$ $-5.0\left(2 \mathrm{H}, \mathrm{NCH}_{2}\right), 5.0-6.0(1 \mathrm{H}, \mathrm{NCH}), 7.0-8.1(9 \mathrm{H}, \mathrm{Ar})$. IIIf- $(-)-2$ (white solid) ; Yield quant. ${ }^{1} \mathrm{H}$ NMR (DMSO$\left.d_{6}\right) \delta 0.0-1.5\left(13 \mathrm{H}, \mathrm{C}_{6} \mathrm{H}_{13}\right), 2.4-3.2\left(6 \mathrm{H}, \mathrm{NCH}_{3}\right), 3.7-$ $4.5\left(4 \mathrm{H}, \mathrm{PhCH}_{2}, \mathrm{OCH}_{2}\right), 4.4-5.3(1 \mathrm{H}, \mathrm{NCH}), 7.0-8.1(4$ $\mathrm{H}$, Ar). IIIf- $(+)-3$ (white solid); Yield 98\%. ${ }^{1} \mathrm{H}$ NMR $\left(\mathrm{DMSO}-d_{6}\right) \delta 0.0-1.5\left(13 \mathrm{H}, \mathrm{C}_{6} \mathrm{H}_{13}\right), 1.7-2.2(3 \mathrm{H}, \mathrm{C}(=\mathrm{O})$ $\left.\mathrm{CH}_{3}\right), 2.4-3.2\left(6 \mathrm{H}, \mathrm{NCH}_{3}\right), 3.7-4.5\left(4 \mathrm{H}, \mathrm{PhCH}_{2}, \mathrm{OCH}_{2}\right)$, $4.4-5.3(1 \mathrm{H}, \mathrm{NCH}), 7.0-8.1(4 \mathrm{H}, \mathrm{Ar})$. IIIf- $(+)-4$ (pale yellow solid); Yield quant. ${ }^{1} \mathrm{H}$ NMR (DMSO- $\left.d_{6}\right) \delta 0.0-$ $1.5\left(21 \mathrm{H}, \mathrm{C}_{6} \mathrm{H}_{13}, \mathrm{C}_{2} \mathrm{H}_{5}, \mathrm{CH}_{3}\right), 2.0-2.4(1 \mathrm{H}, \mathrm{MeCH}), 2.4-$ $3.2\left(6 \mathrm{H}, \mathrm{NCH}_{3}\right), 3.5-4.5\left(2 \mathrm{H}, \mathrm{OCH}_{2}\right), 4.4-5.3(1 \mathrm{H}$, $\mathrm{NCH}$ ), 7.0-8.1 (4H, Ar). IIIf- $(+)-5$ (pale yellow solid); Yield 97\%. ${ }^{1} \mathrm{H}$ NMR (DMSO- $\left.d_{6}\right) \delta 0.5-1.5\left(19 \mathrm{H}, \mathrm{C}_{6} \mathrm{H}_{13}\right.$, $\left.\mathrm{CH}_{3}\right), 1.5-2.0\left(3 \mathrm{H}, \mathrm{CH}-\mathrm{CH}_{2}\right), 2.4-3.2\left(6 \mathrm{H}, \mathrm{NCH}_{3}\right), 3.5$ $-4.5\left(2 \mathrm{H}, \mathrm{OCH}_{2}\right), 4.4-5.3(1 \mathrm{H}, \mathrm{NCH}), 7.0-8.1(4 \mathrm{H}, \mathrm{Ar})$. IIIf- $(-)-6$ (pale yellow solid); Yield quant. ${ }^{1} \mathrm{H}$ NMR $\left(\mathrm{DMSO}-d_{6}\right) \delta 0.0-1.5\left(19 \mathrm{H}, \mathrm{C}_{6} \mathrm{H}_{13}\right), 2.4-3.2\left(6 \mathrm{H}, \mathrm{NCH}_{3}\right)$, $3.2-3.5\left(2 \mathrm{H}, \mathrm{NCH}_{2}\right), 5.0-5.5(1 \mathrm{H}, \mathrm{PhCH}), 7.0-8.1(9 \mathrm{H}$, Ar).

Acknowledgments. The authors are grateful to Professor $H$. Nohira for helpful advice in the preparation of optically pure $\alpha$-methylbenzylamine. The authors also wish to thank Mr. T. Koyama for measurements of Mass spectra.

\section{REFERENCES}

1. a) C. H. Yuan and R. West, Macromolecules, 26, 2645 (1993). b) O. Greszta and K. Matyajaszewski, Macromolecules, 26, 6231 (1993). c) K. Oka, N. Fujiue, S. Nakanishi, T. Tanaka, T. Dohmaru, C. H. Yuan, and R. West, Chem. Lett., 875 (1995). d) K. Oka, N. Fujiue, T. Dohmaru, C. H. Yuan, and R. West, J. Am. Chem. Soc., 119, 4074 (1997).

2. a) R. Kani, Y. Nakano, Y. Majima, S. Hayase, C. H. Yuan, R. West, and I. Keminek, Macromolecules, 27, 1911 (1994). b) R. Horiguchi, Y. Onishi, and S. Hayase, Macromolecules, 21, 304 (1988).

3. a) I. Keminek, E. Brynda, and W. Achnabel, Eur. Polym. J ., 27, 1073 (1991). b) I. Kminek, Y. Yagci, and W. Schmabel, Polym. Bull., 29, 277 (1992). c) T. Seki, T. Tamaki, and K. Ueno, Macromolecules, 25, 3825 (1992). d) T. Seki, A. Tohnai, T. Tamaki, and K. Ueno, J. Chem. Soc. Chem. Commun., 1876 (1993). e) T. Seki, T. Tamaki, K. Ueno, and Y. Tanaka, Thin Solid films, 243, 625 (1994). f) T. Seki, N. Tanigaki, K. Yase, A. Kaito, T. Tamaki, K. Ueno, and Y. Tanaka, Macromolecules, 28, 5609 (1995). g) T. Seki, A. Tohnai, T. Tamaki, and A. Kaito, Chem. Lett., 361 (1996). h) T. Seki, A. Tohnai, T. Tamaki, and A. Kaito, Macromolecules, 29, 4813 (1996). i) T. Seki, A. Tohnai, N. Tanigaki, K. Yase, T. Tamaki, and A. Kaito, Macromolecules, 30, 1768 (1997).

4. a) M. Fujiki, J. Am. Chem. Soc., 116, 6017 (1994). b) M. Fujiki, J. Am. Chem. Soc., 116, 11976 (1994). c) M. Fujiki, Polyme. Prepr., Am. Chem. Soc,. Div. Polym. Chem, 37, 454 (1996). d) M. Fujiki and H.Takigawa, Polym. Prepr. Jpn., 46, 3939 (1997). e) K. Obata and M. Kira, Macromolecules, 31, 4666 (1998).

5. K. Shinohara, T. Aoki, T. Kaneko, and E. Oikawa, Chem. Lett., 361 (1997). b) K. Obata, C. Kubota, and M. Kira, J. Am. Chem. Soc., 119, 11345 (1997).

6. a) H. Ban, K. Sukegawa, and S. Tagawa, Macromolecules, 20, 1775 (1987). b) R. Jones, R. Benfild, A. Swain, S. Webb, and M. Went, Polymer, 36, 393 (1995).

7. D. Terunuma, K. Nagumo, N. Kamata, K. Matsuoka, and H. Kuzuhara, Chem. Lett., 681 (1998)

8. K. Matyjaszewski, D. Greszta, J. S. Hekach, and H. K. Kim, Macromolecules, 28, 59 (1995).

9. H. Nohira, M. Kai, M. Nohira, J. Nishikawa, T. Hoshiko, and K. Saigo, Chem. Lett., 951 (1981). 